\title{
An Analysis of Instructional Material Need For Improving Students' Ability in Writing Cash Flow Reports
}

\author{
Ni Luh Gede Erni Sulindawati \\ Diploma III Program of Accounting Department \\ Universitas Pendidikan Ganesha \\ Singaraja, Indonesia \\ esulind@gmail.com
}

\begin{abstract}
This article was aimed to analyze instructional material need for improving the students' ability to write a cash flow report. The writing of a cash flow report consisted of (1) method and format of a cash flow report; (2) procedure in writing a cash flow report, and (3) analysis of accounts that belong to asset group, liability and equity and the effect on the cash flow. To improve the ability of the students in writing a cash flow report, one can use Microsoft excel media by following three steps, i.e., (1) calculating the difference of the existing accounts; (2) analyzing changes of accounts in the balance sheet by understanding the concept of the effect of the change on cash flow; and (3) presenting the effect of the cash flow report on the cash flow report format
\end{abstract}

Keywords-material, cash flow report, Microsoft Excel

\section{INTRODUCTION}

In her study about cash flow report in a cooperative concludes that cash flow report in the cooperative produces positive cash flow in which there is an increment of cash and cash equivalent is obtained from operational activities[1]. Then, [2] in her article about cash flow report concludes stated that "cash flow greatly affects the measurement of liquidity where, in paying a short-term financial obligation, good cash flow is needed. Furthermore, [3] states that cash flow report and its analysis can be used as a basis management to get a clear image of cash flow. He also mentioned that the company can assess the needs of cash and cash equivalents in the future as well as the possible sources of cash that can be produced by the company. So, the company will work optimally. Those articles analyze the usefulness of cash flow as an analytical tool but not analyze the needs of instructional material to write a cash flow report.

According to [4], Accounting Department is the department which has the competencies or expertise in accounting subject area. The basic expertise qualification in accounting consists of financial accounting, managerial accounting, information system accounting, taxation and computer. To be an expert in financial accounting, the students are required to understand the basic concepts of accounting the process of writing a financial report from an economic entity. The financial report is based the Standard of Financial Accounting that is effective in general which consists of profit-loss report, balance report, retained earnings report and cash flow report. The financial report that was written follows long and very complex process. The process of writing a financial report is often called accounting cycle since the writing follows a long and repeated process. Accounting cycle starts with writing a journal, entering the journal to ledger accounts, writing trial balance, writing adjusting entry, writing a balance sheet and writing a financial report. A financial report that is resulted from the accounting cycle includes a profit-loss report, a balance report, a retained earnings report, and cash flow. A cash flow report can be written from a ledger and equivalent to cash and can also be written from a profit-loss report, two period balances. In the financial accounting standard that is effective in general, every economic entity or a firm, a service undertaking, business and manufacture is obliged to write a cash flow report.

The reality in the field during the educational process, various complex problems appeared, the students found difficulties in matters that are related to mastering and understanding the process of writing a cash flow. To understand the concepts in the writing of a cash flow requires a higher ability from the students. To make it easier for the students to understand the process of writing a cash flow report, they need to be helped with the use of a teaching model, teaching material, or material that is appropriate and tools and equipment or computer program to write a cash flow report. The teaching material needed in the writing of a cash flow should be adjusted to the students' need and the need of the users of information that will use the cash flow information. The problem that is investigated in this article is the instructional material need for improving the students' ability to write a cash flow report consists of the method and format of cash flow report, procedure in writing cash flow report, and analysis of accounts that belong to asset group, liability and equity.

This study used qualitative method which explained about the method and format of cash flow report, procedure in writing cash flow report, and analysis of accounts that belong to asset group, liability and equity. The study used some instruments in collecting the data such as observation guidelines, questioner, interview guidelines and documentation study. The documentation study related to the instructional materials need for writing the cash flow report by analyzing the students' input and report users, identifying 
the objective of learning, and determining the instructional media.

The aimed of writing this article was to identify the material needed in writing a cash flow report. The discussion in this article can be used as material needed in teaching cash flow reports. For the author it can be used as material to develop a course book that is needed in writing a cash flow report.

\section{DISCUSSION}

In the [5] mentioned that a financial report that has to be accounted for by an economic entity consists of (1) balance sheet, (2) profit-loss report,(3) a report about equity changes, (4) a cash flow report and (5) a note about financial report.

A cash flow report is a report that presents relevant information about cash revenues and expenditures of a business unit in one period to the next period. A cash flow is the soul of every business and is the basic need of the progress of business and shows whether it can pay all its obligations. Cash flow is written with the purpose of giving information about the revenue and expenditure of the corporation during a certain period and gives information about operation, investment and financing.

If it's used together with other financial reports such as balance sheet, profit-loss report, held profit report, a cash flow has the use for giving information to the users of to (1) evaluate net asset change, financial structure, and ability to influence cash flow; (2) evaluate the ability of the corporation in producing cash and cash equivalent; (3) use information of historical cash flow as an indicator of amount, time, and certainty of cash flow in the future and (4) use for evaluating the need to use the cash flow by the corporation.

Cash is an element of the working capital which has the highest level of liquidity. The greater the amount of cash the higher it's liquidity. This means that the corporation has a smaller risk not to be able to meet its financial liability. But it does not mean that the corporation has to try to keep a great amount of cash, since the more the amount of the cash is, the more money that is idle so that it reduces its profitability. To maintain the liquidity means to maintain the balance between the flows of money that is expended. To prevent cash difficulty, both having more or less cash, then it is better for the corporation to determine the minimum cash or safety cash. The amount of safety cash is determined by the number of activities or the amount of cash need of the corporation.

The ideal amount of cash needed by the corporation, so far, has been standardized. However, there is a guide to determine the amount of corporation cash. According to H. G. Guthmann [6], the amount of cash that exists in the corporation which is well financed" ideally is not less than $5 \%-10 \%$ of the current asset.

A cash flow report has to report during a certain period and has to clarify the cash flow according o operation activity, investment and financing. The presentation of cash flow according to the three classifications is done according to the most appropriate way according to the characteristics of the corporation business. The incoming cash flow and the outgoing cash flow which is classified according to the activities can be seen in Fig. 1.

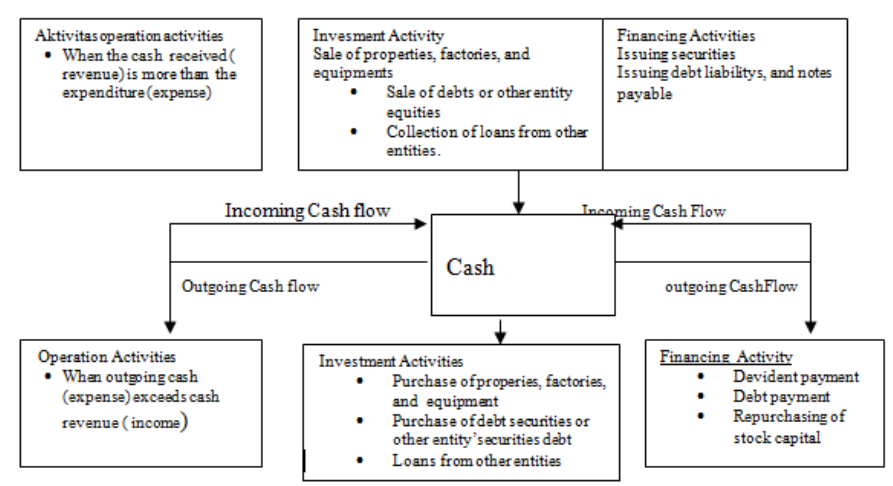

Fig.1. Incoming Cash Flow and Outgoing Cash Flow [7]

\section{A. The Method and format of Cash Flow Report}

There are two methods that can be used to present Cash Flow Report, that is, direct method and indirect method [5]. In the direct method, is reported cash revenue and cash expenditure of the operation activities. The difference between the two amounts is a net cash flow from the operation activity. In other words, the direct method directly subtracts the operation cash expenditure from the cash revenue. In the indirect method, the net profit or loss is adjusted by correcting the effect of the noncash transaction, deferral or accrual from the cash revenue or cash payment for the past operation and in the future and the income components or the expense that is related to the investment or financing cash flow.

Based on SAK ETAP, a cash flow report has to be written using the indirect method. In this method, the net cash flow from the operation activity is determined by adjusting the net profit or loss from the effect from (a) the change in the stock and the loan as well as the debt of the corporation during the current period; (b) the non cash entry such as depreciation, putting some money aside, deferred tax, profit and loss of foreign currencies which have not been realized, the profit of the association corporation that has not been divided and minority's right in the profit/ loss consolidation; and (c) all other entries that are related to investment or financing cash flow.

The cash flow that is classified into three classifications is the common format of a cash flow report. In the first part of the report is presented a cash flow from operation activity, followed by cash flow from investment activity and financing activity, and in the final part is presented an increase and decrease of net cash and cash equivalent during one period.

Things that need to be considered in presenting a cash flow report (1) the cash flow report only reports the cash flow during a certain period and is classified according to operation activity, investment and financing; (2) the corporation presents cash flow and operation activity from operation activity, 
investment and financing by using the most suitable method for the business of the corporation. The classification according to activities gives information that makes it possible for the users to evaluate the effect of the activities on the amount of cash or cash equivalent. The information can also be used to evaluate the relations among the three activities; and a transaction can consist of the cash flow that has been classified into more than one activity; (3) a certain transaction may include cash flow which is classified into two or more activities.

\section{B. Cash flow report format}

In the following section is given an illustration about cash flow format using direct and indirect methods.

\begin{tabular}{|c|c|c|c|}
\hline \multicolumn{4}{|c|}{$\begin{array}{c}\text { PT Sejahtera Utama } \\
\text { Cash Flow Report } \\
\text { The year that ends on the } 31^{\text {st }} \text { of December }\end{array}$} \\
\hline $\begin{array}{l}\text { Cash flow from } \\
\text { Activity: }\end{array}$ & & & \\
\hline Cash revenue from customers & Rp xxx & & \\
\hline $\begin{array}{l}\text { Cash payment to the suppliers } \\
\text { and workers }\end{array}$ & $(\mathrm{xxx})$ & & \\
\hline Payment of interest & $(\mathrm{xxx})$ & & \\
\hline Payment of Income Tax & $(\mathrm{xxx})$ & & \\
\hline $\begin{array}{l}\text { Net cash flow from Operation } \\
\text { Activity }\end{array}$ & & (Rp.xxx) & \\
\hline $\begin{array}{l}\text { Cash flow from Investment } \\
\text { Activity }\end{array}$ & & & \\
\hline $\begin{array}{l}\text { Purchase of land, building and } \\
\text { equipments }\end{array}$ & $\mathrm{xxx}$ & & \\
\hline $\begin{array}{l}\text { Proceeds from the sale of } \\
\text { equipments }\end{array}$ & $\mathrm{xxx}$ & & \\
\hline Revenue from interest & $\mathrm{xxx}$ & & \\
\hline Revenue from dividend & $\mathrm{xxx}$ & & \\
\hline $\begin{array}{lccc}\text { Net cash flow used for } \\
\text { investment activity }\end{array}$ & & (Rp.xxx) & \\
\hline $\begin{array}{l}\text { Cash flow from financing } \\
\text { activity }\end{array}$ & & & \\
\hline Proceeds from sale of equipments & $\mathrm{xxx}$ & & \\
\hline $\begin{array}{l}\text { Proceeds from the issuance of } \\
\text { capital stock }\end{array}$ & $\mathrm{xxx}$ & & \\
\hline Proceeds from long term loan & $\mathrm{xxx}$ & & \\
\hline $\begin{array}{l}\text { Payment of debt of lease for } \\
\text { financial business }\end{array}$ & $\mathrm{xxx}$ & & \\
\hline $\begin{array}{l}\text { Net cash flow used for } \\
\text { financing activity }\end{array}$ & & $\begin{array}{l}\text { (Rp. } \\
\text { Xxx) }\end{array}$ & \\
\hline $\begin{array}{l}\text { Net cash increase and cash } \\
\text { equivalent }\end{array}$ & & & Rp. $x x x$ \\
\hline $\begin{array}{l}\text { Cash and cash equivalent at the } \\
\text { beginning of the period }\end{array}$ & & & Rp. $x x x$ \\
\hline $\begin{array}{l}\text { Cash and cash equivalent at } \\
\text { period end }\end{array}$ & & & Rp. $x x x$ \\
\hline
\end{tabular}

Fig. 2. Direct method cash flow report format [5]

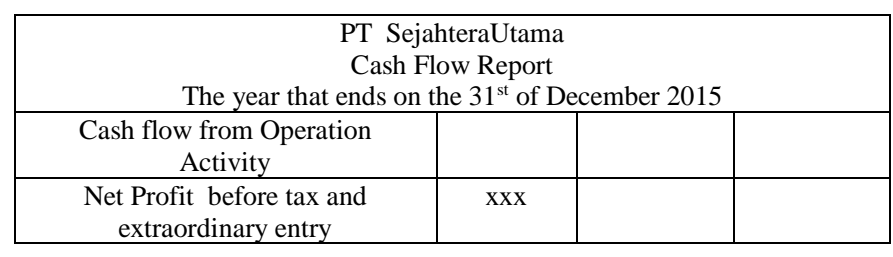

\begin{tabular}{|c|c|c|c|}
\hline \multicolumn{4}{|l|}{ Adjustment for : } \\
\hline Depreciation & $\mathrm{xxx}$ & & \\
\hline Investment Income & $(\mathrm{xxx})$ & & \\
\hline Interest Expense & $\mathrm{xxx}$ & & \\
\hline $\begin{array}{l}\text { Profit of operation before change } \\
\text { in working capital }\end{array}$ & $\mathrm{xxx}$ & & \\
\hline $\begin{array}{l}\text { Increase in business loan and } \\
\text { other loans }\end{array}$ & $(\mathrm{xxx})$ & & \\
\hline Decrease in stocks & $\mathrm{xxx}$ & & \\
\hline Decrease in business debt & $(\mathrm{xxx})$ & & \\
\hline \multicolumn{4}{|l|}{ Cash produced from operation } \\
\hline Payment of interest & $(\mathrm{xxx})$ & & \\
\hline Payment of income tax & $(\mathrm{xxx})$ & & \\
\hline $\begin{array}{c}\text { Net cash flow from operation } \\
\text { activity }\end{array}$ & & $\mathrm{xxx}$ & \\
\hline \multicolumn{4}{|l|}{$\begin{array}{l}\text { Cash flow from Investment } \\
\text { Activity }\end{array}$} \\
\hline $\begin{array}{l}\text { Purchase of land, building and } \\
\text { equipments }\end{array}$ & $\mathrm{xxx}$ & & \\
\hline $\begin{array}{l}\text { Proceeds from the sale of } \\
\text { equipments }\end{array}$ & $\mathrm{xxx}$ & & \\
\hline Revenue from interest & $\mathrm{xxx}$ & & \\
\hline Revenue from dividend & $\mathrm{xxx}$ & & \\
\hline $\begin{array}{lccc}\text { Net cash flow } & \text { used } & \text { for } \\
\text { investment activity } & & \\
\end{array}$ & & (Rp.xxx) & \\
\hline \multicolumn{4}{|l|}{$\begin{array}{l}\text { Cash flow from financing } \\
\text { activity }\end{array}$} \\
\hline Proceeds from sale of equipments & $\mathrm{xxx}$ & & \\
\hline $\begin{array}{l}\text { Proceeds from the issuance of } \\
\text { capital stock }\end{array}$ & $\mathrm{xxx}$ & & \\
\hline Proceeds from long term loan & $\mathrm{xxx}$ & & \\
\hline $\begin{array}{l}\text { Payment of debt of lease for } \\
\text { financial business }\end{array}$ & $\mathrm{xxx}$ & & \\
\hline $\begin{array}{l}\text { Net cash flow used for financing } \\
\text { activity }\end{array}$ & & (Rp. xxx) & \\
\hline $\begin{array}{l}\text { Net cash increase and cash } \\
\text { equivalent }\end{array}$ & & & Rp. $x x x$ \\
\hline $\begin{array}{l}\text { Cash and cash equivalent at the } \\
\text { beginning of the period }\end{array}$ & & & Rp. $x x x$ \\
\hline $\begin{array}{l}\text { Cash and cash equivalent at } \\
\text { period end }\end{array}$ & & & Rp. $x x x$ \\
\hline
\end{tabular}

Fig. 3. Direct method cash flow report format [5]

\section{Steps for writing a Cash Flow}

Different from other major financial reports such as balance sheet, and profit-loss report, a cash flow report is not written from a trial balance after adjustment.

The information needed to write a cash flow report is generally obtained from the following sources: (1) a comparative balance sheet that gives information about asset changes, debts, and savings from the members during a certain period; (2) profit-loss report for cooperatives. A profit loss report is the same as the remaining result of operation (and change in dividend), which gives information about net profit and its components and payment of dividend during a period; and (3) supporting information, that is obtained from an analysis of change in balance sheet accounts that give information about the causes of cash and cash equivalent change.

According to [8] the steps needed in writing a cash flow report both in reporting a direct cash flow report and in reporting an indirect one are (1) to count change in cash or cash equivalent account balance by comparing the beginning 
balance and the final balance which presents a net increase or decrease during the current period; (2) to count the net change of every balance sheet account other than cash account and cash equivalent account and the change category; and (3) to determine cash flow which is separated into three classifications, investment activity, and noncash financing activity and the effect of foreign currencies change which uses information from a comparative balance sheet, the profit loss report of the current period and additional information.

\section{Analysis of accounts that belong to asset, liability and equity}

To be able to classify accounts into operation activity, investment, and financing, there is a need to understand the balance sheet components. The components of balance sheet are Asset, Liability and Equity. Asset consists of current asset, long term investment, tangible fixed assets, intangible fixed assets and other assets.

Debt or liability consists of: current debt, prepaid income, long term debt, and other debts. Equity consists of capital stocks that have been stored, retained earnings, agio/ disagio capital stocks reserves and retained earnings.

Current asset is cash and other assets that are expected will become converted into cash, sold, sold, or consumed in a year or in an operation cycle.

Operation cycle is the average time between the acquisition of material and equipment and the cash realization through the sale of the product. This cycle starts from cash, supply, production and credit, and then goes back to cash again. Current asset is presented in the balance sheet according to the order of liquidity. The five important entries of current asset are cash, long term investment, credit, supply, and prepayment. Cash is reported at its fixed value, short term investment is reported at a reasonable price, business credit is fixed at the estimation of the amount collected, supply is generally reported at whichever is the lower in value between the cost and market price, and prepaid entries are valued at cost.

According to the [5] (PSAK No. 1) an asset is classified as current asset if the asset (1) is estimated to be realized or possessed to be sold or used in the normal operation cycle time of the corporation operation; (2) is possessed to be sold or for a short term and is expected to be realized within one year from the balance sheet data; (3) in the form of cash or cash equivalent and the use of is not limited.

According to [7] if the cash is limited for a purpose other than the paying off of the current liabilities than the amount is not allowed to be stated in the current asset. A short time investment in debt securities and equities are classified into three separate portfolios for of evaluation and reporting purposes. The three portfolios are categorized as follows: (1) securities that are held till the deadline; (2) trade securities, that are the securities which are especially bought and traded to be sold in a short time to earn profit or difference in price within a short time; and (3) securities that are available to be sold or those which are not classified as scurries that are being held until the deadline and trade securities. Trade securities have to be reported as current asset, while the securities that are available to be sold and securities that are being held until the deadline are classified as current or not current asset depended on the situation. All of the trade securities and those that are available to be sold are reported at a reasonable price. Every loss anticipated as the result of nonperforming loan, the amount and characteristics of each non-trade loan, and every loan that was being pawn as collateral has to be identified clearly. To present the supply accurately, the basis for evaluation is whichever the lower between cost or market price and the method for determining FIFO, or LIFO has to be stated. The expense that is prepaid which belongs to current asset which has been done for a profit (usually service) to be got in a year or one operation cycle. Long term investment that is called only as investment usually consists of four types of investment as follows: (1) investment in securities such as liability, common stock, or long term notes payable; (2) investment in tangible fixed asset which is currently used in operation such as land held for speculation; (3) investment put aside in a special fund, such as Repayment fund, retirement fund, or factory expansion; and (4) investment in the branches or affiliations of the corporation which are not consolidated.

Long term investments are usually held for years and are not acquired with the purpose of releasing it in a short time. This entry is usually presented in the balance sheet, which exactly below the Current Asset. Securities which are classified as available securities to be sold have to be reported at a reasonable price. While the ones that are classified as securities that are being held until the deadline are reported at an amortized price.

Properties, factories and equipments are assets that are durable and are used in a regular operation of the corporation. Assets consist of properties, or physical assets such as land, buildings, machines, furniture, tools, and nonrenewable resources except land. Most of these assets can be depreciated.

Intangible assets do not have physical substances and usually have a high level of uncertainty in relation to its future use. Intangible assets consist of patent, property right, good will, trade mark, and secret production process. In general, all of the intangible assets are amortized or deleted as expense for 5 to 40 years.

The entries which were listed in other asset groups are varied such as prepaid long term expenditure, nonperforming loans, prepayment to the branches, etc.

Current liabilities are the liabilities that are estimated to be liquidized through the use of current assets or by creating other current liabilities. According to [5] (PSAK No. 1) a liability is classified as short time liability if (1) it is estimated that it will be paid in a normal operation cycle of the corporation or; (2) the deadline is twelve months from the balance sheet data. Current liabilities consist of entries such as trade notes payable, and nontrade notes payable, business debt, received prepayment from customers, and the current part of long term loan which has been due. 
Long term liabilities are liabilities which are adequately estimated not to be liquefied qualified in the normal operation cycle, but to be paid outside of that time. For example, debt, notes payable, mortgage debt, leases debt, etc.

Owner's equity is the difference between asset and liability and is the corporate responsibility to the owner of the corporation. In a personal corporation, the capital is shown in one account and is called Capital, in a firm the capital is shown in the account of each member and in a company the capital is shown with the capital account that consists of (1) the capital that is given by the share holders and is usually divided into 2 groups, i.e. capital stock and agio or disagio capital stocks (2) retained earnings is a group of earnings from previous years which are not divided as dividends. If it is desired to limit in order that all profits are not divided as dividends, then usually allowance for bad debts from profit are not divided; (3) the reevaluated capitals, if there is an evaluation of the assets of the corporation, then allowance for bad debts from retained earnings; (3) the reevaluation, if there is an evaluation of the assets of the corporation, then the difference between the old book and the new book is recorded as Reevaluated Capital; and (4) capital from donation, if the corporation receives an asset from a donation,
Other capitals are entered into this group if the corporation capital that is reported cannot be entered into one of the groups above.

Once it is known that the accounts belong to current asset, fixed asset, long term liability and equity, they can be grouped into operation activity, investment activity, and financing activity. If the accounts belong to current asset and short term liability, they can be categorized as operation activity, if they belong to fixed asset and long term investment, they can be categorized as investment activity group and if they belong to the long term liability and equity, then they are categorized as financing activity.

After the accounts are categorized into the activities, there is a need to analyze again the effect on the cash flow, if there is an increase in the group of assets, it will cause a reduction in the cash amount, if there is a decrease in assets, it will cause an addition to the cash amount. If there is a reduction in asset group, it will cause cash to become less in amount.

Based on the steps in writing a cash flow report, we can make a cash flow report through Microsoft excel media with the steps as follows.

TABLE 1. COUNTING THE DIFFERENCE OF THE EXISTING ACCOUNTS IN BALANCE SHEET

\begin{tabular}{|c|c|c|c|c|c|}
\hline Account Names & 2014 & 2015 & Difference & Remark & Category \\
\hline Cash & Rp50.000.000 & Rp296.000.000 & Rp246,000,000 & Addition & Cash and cash equivalent \\
\hline Trade Loan & Rp100,000,000 & $\operatorname{Rp} 176,800,000$ & Rp76,800,000 & Addition & Operational \\
\hline Goods Supplies & Rp150,000,000 & Rp93,950,000 & $\operatorname{Rp}(56,050,000)$ & Reduction & Operational \\
\hline Prepaid expense & Rp75,000,000 & Rp50,000,000 & $\operatorname{Rp}(25,000,000)$ & Reduction & Operational \\
\hline Land & Rp200,000,000 & Rp200,000,000 & & Fixed & Investment \\
\hline Building & Rp200,000,000 & Rp200,000,000 & & Fixed & Investment \\
\hline Building Dep Accumulation & Rp50,000,000 & Rp59,000,000 & Rp9,000,000 & Addition & Operational \\
\hline Patents & Rp100,000,000 & Rp100,000,000 & & Fixed & Investment \\
\hline Amortized patents & & Rp2,500,000 & Rp2,500,000 & Addition & Operational \\
\hline Vehicles & & Rp20,000,000 & Rp20,000,000 & Addition & Investment \\
\hline Vehicles Dep Accumulation & & Rp3,000,000 & Rp3,000,000 & Addition & Operational \\
\hline Trade Debts & Rp75,000,000 & Rp157,750,000 & Rp82,750,000 & Addition & Operational \\
\hline Income received in advance & Rp125,000,000 & Rp112,500,000 & $\operatorname{Rp}(12,500,000)$ & Reduction & Operational \\
\hline Interest debt & & Rp6,750,000 & Rp6,750,000 & Addition & Operational \\
\hline Dividend debts & & Rp8,000,000 & Rp8,000,000 & Addition & Operational \\
\hline Expense debt & & Rp750,000 & Rp750,000 & Addition & Operational \\
\hline Long term debt & & & Rp225,000,000 & Fixed & Financing \\
\hline Retained earnings & Rp150,000,000 & Rp311,500,000 & Rp161,500,000 & Addition & Financing \\
\hline Ordinary stock & & & Rp250,000,000 & Fixed & Financing \\
\hline Dividend & & $\operatorname{Rp}(8,000,000)$ & $\mathrm{Rp}(8,000,000)$ & Addition & Financing \\
\hline
\end{tabular}


The second step analyzed the change in accounts in the balance sheet by understanding the concepts, if there is an increase in the asset group, it will cause the reduction in cash amount, if there is a reduction in the asset it will cause an increase in the liability group. If there is an increase in the liability group, it will cause a reduction in assets and this will reduce cash amount.

The third step presented the analysis of the effect of the cash flow analysis on the format of the cash flow report as shown in Fig. 4.

Cash flow Report

Period: the 31 ${ }^{\text {st }}$ of Dec. 2015

\begin{tabular}{|c|c|c|}
\hline Operation Activities & & \\
\hline Addition to Loan & $\operatorname{Rp}(76,800,000)$ & \\
\hline Addition to Retained Earnings & Rp169,500,000 & \\
\hline Reduction in Trade Goods Supply & Rp56,050,000 & \\
\hline Reduction in prepaid expenses & Rp25,000,000 & \\
\hline Addition accumulation Depreciation Building & $\operatorname{Rp}(9,000,000)$ & \\
\hline Addition accumulation Depreciation Vehicle & $\operatorname{Rp}(3,000,000)$ & \\
\hline Addition accounts payable & Rp82,750,000 & \\
\hline Addition debt expend & Rp750,000 & \\
\hline Addition interest payable & Rp6,750,000 & \\
\hline Addition dividend debt & Rp8,000,000 & \\
\hline Reduction in Revenue from deferred earnings & $\operatorname{Rp}(12,500,000)$ & \\
\hline Net cash flow from operation activity & & Rp247,500,000 \\
\hline Investment activity & & \\
\hline Addition to vehicles & $\operatorname{Rp}(20,000,000)$ & \\
\hline Reduction to Patents & $\operatorname{Rp}(2,500,000)$ & \\
\hline Net cash flow from operation activity & & $\operatorname{Rp}(22,500,000)$ \\
\hline Financing activity & & \\
\hline Payment of dividend debts & $\operatorname{Rp}(8,000,000)$ & \\
\hline Flow cash used for financing activity & & $\operatorname{Rp}(\mathbf{8 , 0 0 0 , 0 0 0 )}$ \\
\hline Addition to net cash & & Rp217,000,000 \\
\hline Cash balance the $1^{\text {st }}$ of January, 2015 & & Rp50,000,000 \\
\hline Cash balance per the $1^{\text {st }}$ of March, 2015 & & Rp267,000,000 \\
\hline
\end{tabular}

Fig.4. Cash Flow Report

\section{CONCLUSION}

In the light of discussion above, it can be concluded that the need for the material in teaching the writing of cash flow reports consists of (1) methods and format of cash flow report format; (2) procedure in cash flow report writing; and (3) analysis of accounts included in asset group, liability and equity and their effect on cash flow. To understand the concepts in writing cash flow reports Microsoft excel media can be used by following three stages: (1) counting the difference in the existing accounts in the balance sheet; (2) analyzing changes in the accounts in the balance sheet by understanding the concept of the effect of changes on cash flow; and (3) presenting the analysis of the effect of the cash on the format of cash flow report. So, the contributions of this study could be beneficial for the students and lecturers as an instructional material in writing the cash flow report. For other researchers, the result of this study could be used as a material to develop a textbook in writing the cash flow report by using computer program as a media.

\section{REFERENCES}

[1] N. L. G. E. Sulindawati, "Analisis Statement Of Cashflow Untuk engevaluasi Kemampuan Koperasi Dalam Menghasilkan Kas Dan Setara Kas," J. IKA UNDIKSHA, pp. 46-57, 2013.

[2] C. D. Mogi, A. . Poputra, and S. W. Alexander, "Analisa Laporan Arus Kas Sebagai Dasar Pengukuran Likuiditas Pada Perusahaan 'Unicare' Cabang Manado,” J. BerkalaI lmiah Efisiensi, vol. 11, pp. 33-39, 2016. 
[3] I. Sutomo, "Penyusunan Laporan Arus Kas Dan Analisisnya Pada PT. Bara Mitra Banjarmasin," J. STIE Pancasetia, pp. 182-202, 2012.

[4] Undiksha, Pedoman Studi Program Sarjana dan Diploma Fakultas Ekonomi. Singaraja: Undiksha Press, 2016.

[5] Ikatan Akuntan Indonesia, Standar Akuntansi Keuangan. Jakarta: Salemba Empat, 2002.

[6] B. Riyanto, Dasar-Dasar Pembelanjaan Perusahaan. Edisi 4. Yogyakarta: BPFE, 2010.

[7] D. Kieso and J. Weygant, Akuntansi Intermediate. Edisi Kesepuluh Jilid I (Emil Salim: Penerjemah). Jakarta: Erlangga, 2002.

[8] D. P. Darminto and A. Suryo, Analisis Laporan Keuangan Hotel. Yogyakarta: Andi Offset, 2000. 